\title{
Correlation Between Motivation and Work Environment to Primary School Teachers' Work Commitment
}

\author{
Anak Agung Istri Rahayu Indirayani ${ }^{1 *}$, Maria Goreti Rini Kristiantari ${ }^{1}$ \\ ${ }^{1}$ Universitas Pendidikan Ganesha, Indonesia \\ "Corresponding author. Email: rahayuindira90@ gmail.com
}

\begin{abstract}
Teachers' work commitment takes an important role in education. There are several factors that influence teachers' work commitment, namely teachers' work motivation and teachers' work environment. This study aims to find out the relationship between motivations for teachers' work commitment, the relationship between work environment for teachers' work commitment, and the relationship between motivation and work environment for teachers' work commitment. This research was conducted at SD Gugus Kapten Japa, North Denpasar District using, a non-experimental (ex-post facto) research design. The sampling technique used was a total census/sampling with the number of population was 50 people. The method applied in this research was the non-test method by giving a closed questionnaire. Also, it applied descriptive statistical analysis and inferential statistic methods. Based on the data analysis, it was found that there was a significant relationship between motivation for teachers' work commitment with the value, that was $\mathrm{r}_{\text {count }}=$ $0.604 \geq \mathrm{r}_{\text {table }}=0.279$. There was a significant relationship between work environment for teachers' work commitment with the value, that was $r_{\text {count }}=0.614 \geq r_{\text {table }}=0.279$. Also, there was a significant relationship between motivation and work environment for teachers' work commitment with a significant level of $5 \%$, namely $\mathrm{F}_{\text {count }}=19.157 \geq \mathrm{F}_{\text {table }}=3.195$. This research is useful for teachers in strengthening their work commitment because it requires high work motivation and a supportive work environment, so that it can improve the quality of the nation's education and create the new generation that is able to compete with other countries.
\end{abstract}

\section{Keywords: Teachers' Work Motivation, Teachers'Work Environment, Teachers'Work Commitment}

\section{INTRODUCTION}

Today, global development increases rapidly. The increasing global development requires quality Human Resources (HR). One of the efforts of the government in creating quality Human Resources is by providing education to all citizens. The government continues to strive for the quality of education both in education management and from other aspects. It was shown from changes of curriculum arranged by the government and the improvement of supporting facilities and infrastructure for education. It aims to achieve the goals of national education. It begins with commitment, both from schools, teachers, school staff, parents, and even the students themselves. In this case, educators, especially, teachers have a significant role in developing education quality [1]. In education, teachers are the spearhead of the realization of education [2]. Teacher quality is required in the implementation of education. The teachers' quality can be seen from the work commitment of a teacher.

Commitment is a reference and encouragement that can make a person responsible for the obligations they must carry out [3]. According to Mustaghfiroh et al. [4], a person's commitment to an organization where they work shows someone's involvement in realizing the vision and mission of their organization. Ekalawati et al. [5] stated that commitment is a complete recognition, which is an attitude of character in a person to encourage self-confidence and morale in carrying out tasks towards the better changes. Commitment is a reflection of the extent to which a person is bound and familiar with the organization they are following [6] [7]. Therefore, commitment is a reference and someone's attachment to an organization, so that someone must be responsible for the obligations that must be fulfilled. 
According to Paramitha \& Ihalauw [8], work commitment is the willingness of someone to carry out the task that directly supports the goals of an organization. Teachers' work commitment is also an urge in teachers themselves to maintain their membership and participation in improving the quality of education and achieving the organizational goals of a school [4]. In essence, the teachers' work commitment is an attachment and urge in teachers themselves to participate in achieving the goals of a school in improving the quality of education.

According to Susana [9], there are three components of teachers' work commitment. The first one is an affective commitment which is a commitment influenced by various personal characteristics such as locus of control and even works experiences in the previous workplace. It can influence the work commitment of a teacher. The second one is a normative commitment. It reflects what the teacher should get and give to an organization in their workplace as a reward for what they have done to an organization or their workplace. Lastly, continuance commitment is a commitment that is influenced by the willingness of an individual or the teachers themselves to survive in an organization. With this commitment, teachers are more likely to maintain their jobs than leave their jobs. According to Mustaghfiroh et al., [4]; Werang, [10] there are three components of teachers' work commitment, namely affective commitment, normative commitment, and continuance commitment. Thus, based on the statement of experts regarding the work commitments above, the dimensions of teachers' work commitment was (1) affective commitment with the indicators are the willingness of the teacher to exert all the effort. It is expected to complete the duties and obligations, not complain about their jobs as a teacher, and enthusiastic in carrying out their duties. (2) Normative commitment with the indicators is responsible for providing quality learning, supporting to achieve school organizational goals, and providing the best services. (3) Continuance commitment with indicators are following the school rules, actively participating in school activities, and discipline in academic administration.

Many factors can strengthen the teachers' work commitment in improving the quality of education in this nation, one of which is the teachers' work motivation. Motivation is derived from the word "movere", which means "urge or driving force". Motivation is a driving force of a subject to carry out certain activities to achieve a goal [11][12][13]. Hartanti \& Yuniarsih [14]; Aprida et al., [15] stated that motivation is a form of encouragement and effort both inside and outside of a person that influences voluntary behavior in working for a specific purpose. Motivation is someone's willingness and need, where it is the background for someone to do an action or the background for someone to do a job [16]. Teachers' work motivation is a willingness and need of teachers in carrying out their duties as well as providing energy for a teacher in achieving the goals they expected [17][18][19]. Thus, it can be concluded that teachers' work motivation is a willingness within the teacher themselves to carry out something in order to be able to achieve the goals they expected. Teachers who have high work motivation can be seen from how they complete their responsibility as a teacher [20][21]. According to Pianda [22], there are three dimensions of teachers' work motivation. Those are responsibility, discipline, and achievement. Responsibility is a teacher's responsibility in carrying out their duties. Discipline as one of the dimensions of teachers' work motivation refers to complete a task and prioritize something. The last is an achievement, which is not only referred to as the achievement in getting an award but also the achievement in a broader context. It can be the achievement of respecting the opinions of others and establishing good relationships with people in the environment. Furthermore, Kartini \& Kristiawan [23]; Endin [24], stated that the teachers' work motivation includes several indicators such as teachers' responsibility in carrying out their tasks according to the curriculum applied, having clear and challenging goals, having feedback of the results of their work, working wholehearted, and always outperformed others. Dwiyani \& Sarino [25] also argued that the indicators of teachers' work motivation consist of four indicators which were responsibility in carrying out tasks, achievement achieved by the teacher, selfdevelopment, and independence in action. Based on some statements stated by the experts, it can be concluded that there are some dimensions of teachers' work motivation. The first one is the responsibility with the indicators consists of preparing learning activities as good as possible, correcting students' work, giving assignments if unable to attend school, attending school on time, and guiding as well as directing students. The second dimension is discipline. Discipline referred is in carrying out the tasks, duties, and giving full attention to the school development. The last dimension is an achievement that includes respecting opinions, supporting and improving work performance, maximize existing facilities and infrastructure.

In addition to teachers' work motivation, the teachers' work environment can also influence teachers' work commitment. The work environment is the most important component for teachers in carrying out their work [26]. The work environment can affect the teachers' work commitment because it can create morale so that it can strengthen the teachers' work commitment [27]. According to [28], teachers' work environment is everything around the teacher when the teacher is working. It can be something physically and nonphysically or directly or indirectly which can influence the teacher when they are working. A work environment that can strengthen teachers' work commitment is a work environment that conducive and can provide a sense of 
security so that teachers will work more optimally [29][30]. In addition to the work environment that conducive, the suitability of the work environment can also influence the implementation and morale of the teacher [31][32][33]. The work environment is a workplace of the teachers or the place where the teachers do all of their works in accordance with their respective duties [34][35]. Efendi et al. [36] stated the work environment is a condition that can be prepared in advance by the organization when establishing the workplace. Putrayana et al. [37], said that the work environment is a condition that has a big influence on schools both in workplace settings such as lighting, cleanliness, air circulation, color regulation, noise, and job security as well as others. Manik \& SYafrina [38] also argued that the work environment is a condition in an organization in both material and psychological terms. Thus, the work environment is the teachers' workplace or a place for teachers to do all activities related to their work both physically and non-physically. According to Sutaji et al. [39], the work environment consists of a family context, good communication, self-control, work equipment, and cleanliness of the workplace. According to Prahasti \& Wahyono [40], indicators of the work environment consist of work context, relationships with colleagues, and the availability of work facilities. Therefore, it can be concluded that the work environment consists of two dimensions, namely physical and nonphysical environment. The indicators of the physical environment are lighting, air circulation, noise, coloring, and work facilities. On the other hand, the indicators of a non-physical environment are the working relationship between teachers and superiors as well as the relationship between teachers and their colleagues. The purpose of this research is to find out the relationship between motivation to teachers' work commitment, the relationship between work environment to teachers' work commitment, and the relationship between motivation and work environment to teachers' work commitment. Also, it can be used as a material in strengthening the teachers' work commitment.

\section{METHODS}

This research was non-experimental (ex post facto) that was conducted on the civil servant teachers at Gugus Kapten Japa, North Denpasar District with a number of population was 50 people. This study aimed to find out how was the relationship between the motivation and work environment to the work commitment of teachers in Primary School at Gugus Kapten Japa, North Denpasar District. The sample was conducted using the census or sampling total method. The method of collecting data applied in this research was the non-test method using a questionnaire. This research used a close questionnaire, where the respondents were asked to choose the answer to the questions arranged by the researcher. In the statement, there were four answer options. The answer options provided in the questionnaire were Strongly Agree (SA), Agree (A), Disagree (D), and Strongly Disagree (SD). For quantitative analysis needs, the answers to the questionnaire were scored using a Likert Scale with four answer choices [50]. The Likert scale is usually used to measure a person's perception or attitude desired by researchers. This questionnaire was analyzed using the construct validity, item validity, and reliability test.

This research used descriptive statistical analysis and inferential statistics methods. In testing hypotheses I and II, it used the product-moment correlation test, while testing hypotheses III used multivariate correlation or commonly called multiple correlations. However, before testing the hypothesis, at first, the researcher conducted a prerequisite test, namely: normality test, linearity test, and multicollinearity test.

Table 1. The Results of Descriptive Statistics Calculation

\begin{tabular}{|l|c|c|c|}
\hline \multirow{2}{*}{ Statistics } & \multicolumn{3}{|c|}{ Variable } \\
\cline { 2 - 4 } & $\begin{array}{c}\text { Teachers' } \\
\text { Work } \\
\text { Motivatio } \\
\text { n }\end{array}$ & $\begin{array}{c}\text { Teachers' } \\
\text { Work } \\
\text { Environm } \\
\text { ent }\end{array}$ & $\begin{array}{c}\text { Teachers' } \\
\text { Work } \\
\text { Commitm } \\
\text { ent }\end{array}$ \\
\hline $\begin{array}{l}\text { Number of } \\
\text { Samples }\end{array}$ & 50 & 50 & 50 \\
\hline Mean & 104 & 104.78 & 100.56 \\
\hline Median & 105.5 & 103 & 102 \\
\hline Modus & 92 & 95 & 100 \\
\hline $\begin{array}{l}\text { Standard } \\
\text { Deviation }\end{array}$ & 10.57914 & 9.8110516 & 11.351813 \\
\hline Variance & 111.9183 & 96.256734 & 128.86367 \\
\hline $\begin{array}{l}\text { Minimum } \\
\text { Score }\end{array}$ & 85 & 89 & 74 \\
\hline $\begin{array}{l}\text { Maximum } \\
\text { Score }\end{array}$ & 122 & 127 & 120 \\
\hline
\end{tabular}

\section{RESULTS AND DISCUSSIONS}

Based on the data collected using a questionnaire distributed via a google form, the results of descriptive statistical testing can be seen as follows.

Before conducting the hypothesis test, the researcher conducted a prerequisite test. It was examined with the assistance of IBM Statistic 21.0. The result of the first prerequisite test was the normality test. It aimed to find out whether the data studied had been normally distributed or not. It was obtained using the KolmogorovSmirnov formula. This test was carried out with a significant level of $0.05 \%$. The test results are as follows. 
Table 2. The Results of Normality Test

\begin{tabular}{|l|c|c|}
\hline \multicolumn{1}{|c|}{ Variable } & $\begin{array}{c}\text { Kolmogorov- } \\
\text { Smirnor }\end{array}$ & Remarks \\
\hline Work Motivation & 0.669 & Normal \\
\hline Work Environment & 0.581 & Normal \\
\hline Work Commitment & 0.478 & Normal \\
\hline
\end{tabular}

The result of the second prerequisite test was linearity. It was conducted using a linearity test with a significant level of $0.05 \%$. The test results are as follows.
Table 3. The Results of Linearity Test

\begin{tabular}{|l|c|c|}
\hline Linear Relationship & $\begin{array}{c}\text { Kolmogorov- } \\
\text { Smirnor }\end{array}$ & Remark \\
\hline $\begin{array}{l}\text { Teachers' work } \\
\text { motivation on } \\
\text { teachers' work } \\
\text { commitment }\end{array}$ & 0.205 & Linear \\
\hline $\begin{array}{l}\text { Teachers' work } \\
\text { environment on } \\
\text { teachers' work } \\
\text { commitment }\end{array}$ & 0.037 & Linear \\
\hline
\end{tabular}

The results obtained in the third prerequisite test, namely the multicollinearity test, are as follows.

Table 4. The Results of Murticollinearity Test

\begin{tabular}{|c|c|c|c|c|c|c|c|c|}
\hline \multicolumn{9}{|c|}{ Coefficients } \\
\hline \multirow{2}{*}{\multicolumn{2}{|c|}{ Model }} & \multicolumn{2}{|c|}{$\begin{array}{l}\text { Unstandardized } \\
\text { Coefficients }\end{array}$} & \multirow{2}{*}{\begin{tabular}{|c|}
$\begin{array}{c}\text { Standardized } \\
\text { Coefficients }\end{array}$ \\
Beta
\end{tabular}} & \multirow{2}{*}{$\mathbf{t}$} & \multirow{2}{*}{ Sig. } & \multicolumn{2}{|c|}{ Collinearity Statistics } \\
\hline & & $\mathrm{B}$ & Std. Error & & & & Tolerance & VIF \\
\hline \multirow{3}{*}{1} & (Constant) & 14.637 & 13.970 & & 1.048 & .300 & & \\
\hline & $\begin{array}{l}\text { Teachers' Work } \\
\text { Motivation }\end{array}$ & .379 & .154 & .354 & 2.471 & .017 & .573 & 1.746 \\
\hline & $\begin{array}{l}\text { Teachers' Work } \\
\text { Environment }\end{array}$ & .444 & .166 & .383 & 2.679 & .010 & .573 & 1.746 \\
\hline
\end{tabular}

In this research, three hypotheses were using the significant level of $0.05 \%$. In testing hypothesis I, it was carried out using the product-moment correlation test. It was found that there was a significant relationship between teachers' work motivation and teachers' work commitment with the value of $r_{\text {count }}$ was $0.604 \geq r_{\text {table }}$ 0.279 . In testing hypothesis II, it was carried out using the product-moment correlation with the testing results showed that there was a significant relationship between teachers' work environment and teachers' work commitment with the value of $r_{\text {count }} 0.614 \geq r_{\text {table }} 0.279$. In testing hypothesis III, it was carried out using multiple correlation tests with a significant level of $0.05 \%$. The results obtained from the test showed that there was a relationship between motivation and work environment to teachers' work commitment with the value of $F_{\text {count }}$ $19.157 \geq F_{\text {table }} 3.195$.

Based on the results explained above, this research used descriptive statistical tests and inferential statistical tests. The descriptive statistical was used to see the results of the research generally, while the inferential statistical tests were used to count the hypotheses in this research. Before calculating the hypotheses, three prerequisite tests should be fulfilled. Those were normality test, linearity test, and multicollinearity. The normality test aimed to see whether the data collected is normally distributed or not. Good data used and can be continued in the process of calculating the hypothesis was data that was normally distributed, so that later in the data processing processed there was no bias. In this research, the normality tests applied the KolmogorovSmirnov formula that was counted using the assistance of IBM SPPS Statistic 21.0 with the significant level of $5 \%$. Thus, it obtained the results that the value of the work motivation variable was 0.669 , the work environment variable was 0.581 , and the work commitment variable was 0.478 . After carrying out the normality test, the linearity test was tested using a significance level of $5 \%$. The results showed that there was a linear relationship between work motivations to teachers' work commitment with the value of 0.205 . Also, there was a linear relationship between the work environments to teachers' work commitment with a value of 0.037 . Then, the final prerequisite test was the multicollinearity test between independent variables. The multicollinearity test was carried out to see whether there was or not a relationship between the independent variables and one another. The results obtained showed that there was no relationship between work motivation variables and work environment variables. It can be seen from the calculation of Tolerance (TOL) and Variance (VIF), which was calculated with the assistance of IBM SPSS Statistic 21.0, which was the TOL value of 0.573 and VIF value of 1.746 .

After the prerequisites are fulfilled by carrying out these three tests, then the calculation of the hypothesis was carried out using a significance level of 5\%. It aimed to see whether there is or not a relationship between the 
independent variable and the dependent variable in this study. The first and second hypotheses, it was calculated using the product-moment correlation formula. In hypothesis I, the results obtained showed that the value of $r$ count was $0.604 \geq r$ table 0.279 . In other words, there was a significant relationship between work motivations to teachers' work commitment. The results of this research were in accordance with the results of the research conducted by Sudaryana et al, [41]. He stated that there was a significant relationship between motivations and work commitment. The correlation obtained in his research was 0.604 with a significant level of $0.05 \%$. The research conducted by Suputra and Sriathi [42] showed that there was a significant positive influence between work motivation and organizational work commitment of 1.158 with a significance level of $0.05 \%$. Besides, the research conduct by Putri [43] also showed that there was a relationship between work motivation and work commitment to employees with the results of $\mathrm{t}$ test was $\mathrm{t}_{\text {count }}=7.88>\mathrm{t}_{\text {table }}=2.021$ at the $95 \%$ confidence level. Basically, work motivation is the strength or willingness of a person to do and complete the tasks. Therefore, the higher a person's work motivation, the higher the work commitment they have and vice versa. The lower a person's work motivation, the lower the work commitment they have.

The result of hypothesis II testing showed that there was a significant relationship between the work environments to teachers' work commitment with the value of $r_{\text {count }}$ was $0.614 \geq r_{\text {table }} 0.279$. This result was in line with the results of research conducted by Rumoning [44] that showed there was an influence between work environments the organizational commitment with the $\mathrm{t}$ value of $1.655<2.003$. The research conducted by Ningsih [45] had a similar result that showed the work environments had a significant positive influence on teacher performance with the value of sig $t$ was $<0.05$ at the confidence level of $95 \%$. In accordance with those results, the results of research conducted by Oktiyani \& Nainggolan [46] provided the result that showed work environments had a positive and significant influence on teacher performance. It was known from the $t$ count of $4.648>\mathrm{t}$ table $(2.000)$ at a significant level of $5 \%$. Also, the definition of work environment according to Adha et al. [28], stated that work environment is everything that exists around the teacher, both physically and nonphysically that can influence the work of the teacher.

The results of hypothesis III were counted using multiple correlation formula. It obtained that was a significant relationship between motivation and work environments on the teachers' work commitment with the value of $F$ count $19.157 \geq F$ table 3.195 . This finding was in line with the research obtained by Bukhari \& Pasaribu [47] that showed simultaneously motivation, competence, and work environment had a positive and significant influence on the employees' performance of PDAM Tirta Tamniang, Aceh Tamiang Regency, with a value of $F_{\text {count }} 25.976>F_{\text {table }} 2.55$ and the significant value of $0.000<0.05$. Similarly, the research conducted by Supriyanto \& Mukzan [48] showed that there was a positive and significant simultaneous and partial influence between work motivation and work environment on the performance of LPP RRI Malang Station employees. Besides, the research conducted by Hidayahti [49] showed similar results which were work environment, motivation, and organizational commitment simultaneously had a significant influence on employee performance with the value of $\mathrm{R}$ square was $0.516(51.6 \%)$. It means work environment, motivation, and organizational commitment give an influence of $51.6 \%$ on the performance of production employees at CV. Juke Abadi Sidoarjo. The work motivation appears both from inside or outside of the teacher themselves. The environment greatly influences the teachers' motivation. If the teacher is in an environment that has a high motivation to achieve the goals they want, it will directly have an impact on the teacher. Therefore, the teacher who has work motivation will be motivated by a work environment that has high work motivation. Thus, there is a significant relationship between teachers' workmotivationa and teachers' work environment.

\section{CONCLUSION}

This research concluded that there is a significant relationship between teachers' work motivation and the work commitment of elementary school teachers in Gugus Kapten Japa, North Denpasar District. In addition, the results of this research also show that there is a significant relationship between the work environment and the work commitment of elementary school teachers in gugus Kapten Japa, North Denpasar District. Teachers who have strong work commitment are teachers who have high work motivation. Therefore, high work motivation is required to strengthen the teachers' work commitment. Thus, the purposes of teachers participating in achieving the goals of schools by improving the quality of education can be achieved. In addition, the environment is one of the factors that can strengthen the teachers' work commitment. A work environment that has adequate facilities both physically and nonphysically can strengthen the teachers' work commitment.

The suggestions to be conveyed to teachers, school principals, and other researchers based on the research conducted is to further strengthen work commitment to getting the maximum results as expected.

\section{ACKNOWLEDGMENTS}

Thanks to God Almighty for His grace this article can be completed. My gratitude to those who have helped me, so that this article can be completed properly. Without the help of all related parties, this research will not complete as expected. 


\section{REFERENCES}

[1] N. L. P. Sri Laksmi, A. A. Gede Agung, Sudirman, Hubungan kepemimpinan pelayan, kompetensi manajerial kepala sekolah, budaya organisasi, dan motivasi kerja dengan kinerja guru di Gugus PAUD Tunjung Kecamatan Denpasar Utara, Jurnal Administrasi Pendidikan Indonesia 10(2) (2019) 148-156.

DOI: https://doi.org/10.23887/japi.v10i2.2802

[2] N. K. T. F. Subagia, M. Yudana, D. G. H. Divayana, Kontribusi supervisi klinis kepala sekolah, motivasi kerja, iklim kerja dan tunjangan profesi terhadap kepuasan kerja guru TK di Kecamatan Kuta Utara, Jurnal Administrasi Pendidikan Indonesia 10(2) (2019) 101-110.

[3] M. Sahnan, M. Ritonga, Kontribusi komitmen kerja dan iklim sekolah terhadap kepuasan kerja guru SMA Kecamatan IV Jurai Pesisir Selatan, INFERENSI: Jurnal Penelitian Sosial Keagamaan, 12(2) (2019) 417-434. DOI: https://doi.org/10.18326/infs13.v12i2.417-434

[4] Mustaghfiroh, N. S. Ariyanti, M. A. Adha, Sultoni. Upaya peningkatan komitmen kerja guru bidang studi, Jurnal Dinamika Manajemen Pendidikan (JDMP) 5(1) (2020) 22-28.

[5] R. Ekalawati, H. Fitria, Mulyadi, Pengaruh kepemimipinan kepala sekolah dan komitmen kerja terhadap profesionalisme guru, Jurnal Al Qiyam, 1(1) (2020) 173-179.

[6] U. Khasanah, L. A. A. Aulia, Hubungan antara kepuasan akan gaji, kecerdasan emosional dengan komitmen kerja, Jurnal Psikologi, 7(September), 2020 , 157-172. https://www.jurnal.yudharta.ac.id/v2/index.php/IL MU-PSIKOLOGI/article/view/2422

[7] I. S. Saragih, D. Suhendro, Pengaruh iklim organisasi sekolah, budaya kerja guru, dan kepuasan kerja terhadap komitmen kerja guru, Jurnal Akuntabilitas Manajemen Pendidikan 8(1) (2020) 44-52. DOI: https://doi.org/10.21831/jamp.v8i1.29654

[8] Y. Paramitha, J. J. O. I. Ihalauw, Persepsi generasi Y mengenai pekerjaan, komitmen kerja, dan keberlanjutan kerja, Journal Of Business \& Applied Management 11(2) (2018) 155-173.

[9] Susana, Supervisi akademik dan komitmen kerja guru terhadap kinerja mengajar guru, Jurnal Administrasi Pendidikan 25(1) (2018) 120-128.

[10] B. R. Werang, Pengaruh keterampilan managerial kepala sekolah dan iklim sekolah terhadap komitmen kerja guru sekolah dasar Kristen di Kabupaten Boven Digoel, Al Ibtida: Jurnal Pendidikan Guru MI
5(2) (2018) $159 . \quad$ DOI:

https://doi.org/10.24235/al.ibtida.snj.v5i2.2650

[11] D. Anggrayni, H. Sarwiji, Susantiningrum, Pengaruh motivasi kerja dan lingkungan kerja terhadap kinerja guru SMK Pancasila 6 Jatisrono Kecamatan Jatisrono Kabupaten Wonogiri, Jurnal Informasi Dan Komunikasi Administrasi Perkantoran 2(2) (2018) 41-49. http://jurnal.fkip.uns.ac.id/index.php/jikap

[12] N. Amalda, L. D. Prasojo, Pengaruh motivasi kerja guru, disiplin kerja guru, dan kedisiplinan siswa terhadap prestasi belajar siswa, Jurnal Akuntabilitas Manajemen Pendidikan 6(1) (2018) 11. DOI: https://doi.org/10.21831/amp.v6i1.7515

[13] S. Fujiaturrahman, Hubungan Iklim Sekolah Dengan Motivasi Kerja Guru, Jurnal Elementary, 1(1) (2018) 31.

DOI: https://doi.org/10.31764/elementary.v1i1.143

[14] A. S. Hartanti, T. Yuniarsih, Pengaruh kompetensi profesional guru dan motivasi kerja terhadap kinerja guru di sekolah menengah kejuruan, Jurnal Pendidikan Manajemen Perkantoran 3(1) (2018) 167. DOI: https://doi.org/10.17509/jpm.v3i1.9452

[15] Y. Aprida, H. Fitria, Nurkhalis, Pengaruh supervisi kepala sekolah dan motivasi kerja guru terhadap kinerja guru, Journal of Education Research 1(2) (2020) 160-164. DOI https://doi.org/10.37985/joe.v1i2.16

[16] Masykur, Ruhban, Septuri, Y. Setiawan, Pengaruh budaya organisasi terhadap motivasi kerja guru di sekolah dasar ar-raudah bandar lampung, Al-Idarah: Jurnal Kependidikan Islam, 9(Juni 2019).

[17] R. S. Dewi, T. C. Kurniaitun, Abubakar, Kemampuan profesional guru dan motivasi kerja terhadap kinerja mengajar guru sekolah dasar. Jurnal Administrasi Pendidikan 25(1) (2018) 150-159. DOI: https://doi.org/10.17509/jap.v25i1.11581

[18] V. N. V. Harling, M. D. T. Sogen, Analisis hubungan motivasi kerja, kompetensi dosen, kepemimpinan, lingkungan kerja dan komitmen profesi terhadap kinerja dosen Politeknik Katolik Saint Paul Sorong. SOSCIED, 1(1), 2018.

[19] Danial, M. Damopolii, S. Syamsudduha, Hubungan antara iklim dan budaya madrasah dengan motivasi kerja guru pada Madrasah Tsanawiyah di Kecamatan Sinjai Barat Kabupaten Sinjai, 14(1), 2019, pp. 6072.

[20] M. Herawati, I. Suyahya, F. Hapsari, Motivasi kerja guru dan pengaruhnya pada kinerja guru di Yayasan Islam Al Ma'ruf, Research and Development Journal Of Education 5(2) (2019) 102-112. 
[21] S. Sabania, Hubungan motivasi kerja dengan profesionalisme guru SD Sekecamatan Wawotobi Kabupaten Konawe, Journal of Chemical Information and Modeling 11(2) (2018) 109-126.

[22] D. Pianda, KINERJA GURU: Kompetensi Guru, Motivasi Kerja, Kepemimpinan Kepala Sekolah, CV. Jejak, 2018.

[23] D. Kartini, M. Kristiawan, Pengaruh tunjangan profesi dan motivasi kerja terhadap kinerja guru, Kelola: Jurnal Manajemen Pendidikan 6(1) (2019) 25-33.

[24] Endin, Analisis hubungan motivasi dan kepuasan kerja dengan kedisiplinan guru pendidikan agama islam di sekolah dasar, Jurnal Educatio FKIP UNMA, 6(1) (2020) 1-7. DOI: https://doi.org/10.31949/educatio.v6i2.594

[25] D. Diwiyani, A. Sarino, Gaya kepemimpinan situasional kepala sekolah dan motivasi kerja guru sebagai determinan kinerja guru, Jurnal MANAJERIAL, 17(1) (2018) 83. DOI: https://doi.org/10.17509/manajerial.v17i1.9763

[26] S. Sofyan, D. Prasada, I. R. Akbar, Pengaruh motivasi, lingkungan kerja dan kepuasan kerja terhadap kinerja guru SMP/MTs Muhammadiyah Cabang Sawangan, Jurnal Ilmu Komputer Dan Bisnis, 11(2a) (2020) 33-44. DOI: https://doi.org/10.47927/jikb.v11i2a.256

[27] Pujianto, Y. Arafat, A. A. Setiawan, Pengaruh supervisi akademik kepala sekolah dan lingkungan kerja terhadap kinerja guru Sekolah Dasar Negeri Air Salek, Journal of Education Research, 1(2) (2020) 106-113. DOI: https://doi.org/10.37985/joe.v1i2.8

[28] R. N. Adha, N. Qomariah, A. H. Hafidzi, Pengaruh motivasi kerja, lingkungan kerja, budaya kerja terhadap kinerja karyawan Dinas Sosial Kabupaten Jember, Jurnal Penelitian IPTEKS 4(1) (2019) 47.

[29] E. Putra, Pengaruh fasilitas kerja, lingkungan kerja, dan budaya organisasi terhadap semangat kerja guru pada MTs Al-Huda PekanBaru, Riau Economics and Business Reviewe 9(1) (2018) 19.

[30] R. A. Mulia, N. Saputra, Pengaruh kompetensi lingkungan kerja dan motivasi berprestasi terhadap kinerja Pegawai Negeri Sipil Sekretariat Daerah Kota Padang, Jiee 1(1) (2020) 51.

[31] R. D. Parashakti, Putriawati, Pengaruh Keselamatan dan Kesehatan Kerja (K3), lingkungan kerja dan beban kerja terhadap kinerja karyawan, 1(3) (2020) 290-304. DOI: https://doi.org/10.31933/JIMT
[32] E. Warna, Suratno, Tiara, Pengaruh upah kerja penghargaan dan lingkungan kerja terhadap motivasi kerja Guru Ekonomi di SMA Negeri Se Kota Jambi, Jurnal Manajemen Pendidikan Dan Ilmu Sosial 1(2) (2020) 354-369. DOI: https://doi.org/10.38035/jmpis.v1i2.274

[33] D. Handayani, D. Pengaruh pendidikan dan pelatihan, motivasi, serta lingkungan kerja terhadap kinerja guru SMK Negeribanyuasin, Jurnal Ilmu Manajemen 6(2) (2019) 140. DOI: https://doi.org/10.32502/jimn.v6i2.1583

[34] A. T. Haryanto, S. N. Dewi, S. Fatonah, Jurnal basicedu, Jurnal Basicedu 3(2) (2020) 524-532.

[35] E. Herjany, D. I. Bernarto, Pengaruh lingkungan kerja, kepuasan kerja, dan stres kerja terhadap komitmen organisasi Guru TK dan SD pada Sekolah $\mathrm{X}$ di Jakarta Barat, Jurnal Manajemen Indonesia 18(2) (2018) 154-164.

[36] S. Efendi, P. S. Prakoso, S. Pulungan, S. Rahmadani, S. U. A. Nasution, Pengaruh lingkungan kerja, disiplin dan tunjangan profesi guru terhadap kinerja guru Madrasah Aliyah Negeri 3 Tapanili Selatan, Jurnal Riset Akuntansi Multiparadigma (JRAM) 7(2) (2020) 248-259. DOI: https://doi.org/10.30596/edutech.v6i1.4391

[37] G. K. Putrayana, A. A. G. Agung, I. G. K. A. Sunu, Analisis determinasi gaya gaya kepemimpinan kepala sekolah, manajemen mutu, lingkungan kerja, dan komitmen kerja terhadap kepuasan kerja guru SMA Negeri 1 Mengwi 9(1) (2018) 77-87.

[38] S. Manik, N. Syafrina, Pengaruh lingkungan kerja terhadap kinerja guru pada Sekolah Dasar Negeri 009 Kuala Terusan Kecamatan Pangkalan Kerinci, Eko Dan Bisnis: Riau Economic and Business Review 9(3) (2018) 158-167. https://ekobis.stieriauakbar.ac.id/index.php/Ekobis/article/view/29/25

[39] K. Sutaji, M. Akbar, Matin, Pengaruh lingkungan kerja dan self efikasi terhadap efektifitas kerja guru SMP Negeri di Kecamatan Bekasi Utara 10, 2019. pp. 135-147.

[40] S. Prahasti, Wahyono, Pengaruh gaya kepemimpinan, budaya organisasi, dan lingkungan kerja terhadap kinerja pegawai dengan kepuasan kerja sebagai mediator, Economic Education Analysis Journal 7(2) (2019) 543-552.

[41] I. G. S. Sudaryana, M. Yudana, Sudirman, Kontribusi kepemimpinan, motivasi kerja, iklim kerja dan kepuasaan kerja terhadap komitmen pegawai Laboratorium di Undiksha, Jurnal Administrasi Pendidikan Indonesia 10(1) (2019) 5665. 
[42] I. D. N. S. A. Suputra, A. A. A. Sriathi, Pengaruh motivasi kerja dan kepuasan kerja terhadap komitmen organisasional 7(9) (2018) 4628-4656.

[43] F. I. Putri, Hubungan motivasi kerja dengan komitmen kerja karyawan di balai pendidikan dan pelatihan social, Jurnal Administrasi Penidikan, 2(1) (2014)

file:///C:/Users/user/AppData/Local/Temp/3756-

7817-1-SM.pdf

[44] M. H. Rumoning, Pengaruh lingkungan kerja, disiplin kerja dan stres kerja terhadap komitmen organisasi dalam meningkatkan kinerja perawat di Rsud Kabupaten Asmat, Jurnal EMBA: Jurnal Riset Ekonomi, Manajemen, Bisnis Dan Akuntansi 6(2) (2018) 958-967. DOI: https://doi.org/10.35794/emba.v6i2.19946

[45] P. Ningsih, Kabupaten Mamuju Utara (study kasus pada SMA Negeri 1 Pasangkayu dan MA DDI Pasangkayu), Kataogis 4(11) (2016) 127-137.

[46] R. Oktiyani, K. Nainggolan, Analisis pengaruh kompensasi dan lingkungan kerja terhadap kinerja guru di SMA Negeri 1 Klaten, Ecodemica IV(2) (2016)

http://ejournal.bsi.ac.id/ejurnal/index.php/ecodemic a

[47] Bukhari, S. E. Pasaribu, Pengaruh motivasi, kompetensi, dan lingkungan kerja terhadap kinerja, Maneggio: Jurnal Ilmiah Magister Manajemen, Vol 2(1) (2019) 89-103. http://journal.umsu.ac.id/index.php/MANEGGIO/ar ticle/view/3365

[48] H. Supriyanto, M. D. Mukzam, Pengaruh motivasi kerja dan lingkungan kerja terhadap kinerja karyawan (studi pada Karyawan LPP Radio Republik Indonesia Stasiun Malang), Jab 58(1) (2018) 141-146. http://administrasibisnis.studentjournal.ub.ac.id/ind ex.php/jab/article/download/2415/2810

[49] D. N. Hidayahti, Pengaruh lingkungan kerja, motivasi, dan komitmen organisasional terhadap kinerja karyawan bagian produksi pada Cv. Juke Abadi Sidoarjo, JEM17: Jurnal Ekonomi Manajemen 4(1) (2019) 22-32. DOI: https://doi.org/10.30996/jem17.v4i1.2910

[50] Sukardi, Metodologi Penelitian Pendidikan Kompetensi dan Praktiknya, Bumi Aksara, 2019. 